\title{
PREPARASI PEREAKSI KIT IMMUNORADIOMETRICASSAY FREE PROSTATE SPECIFIC ANTIGEN UNTUK DETEKSI KANKER PROSTAT
}

\author{
PREPARATION KIT REAGAN OF IMMUNORADIOMETRICASSAY FREE \\ PROSTATE SPECIFIC ANTIGEN KIT REAGEN FOR PROSTATE CANCER \\ DETECTION
}

\section{Puji Widayati*), Gina Mondrida, Sri Setiyowati, Agus Ariyanto, V. Yulianti Susilo, Wening Lestari}

\author{
Pusat Radiosotop dan Radiofarmaka-BATAN, \\ Kawasan PUSPIPTEK Serpong, Tangerang Selatan, Banten Indonesia \\ Email: pujiw@batan.go.id
}

Diterima: 19 Agustus 2013, Direvisi: 8 Agustus 2013, Disetujui: 20 September 2013

\begin{abstract}
ABSTRAK
Prostate Specific Antigen adalah glikoprotein dengan berat molekul 34.000 dalton yang diproduksi terutama oleh sel-sel epitel yang melapisi asinus dan saluran kelenjar prostat. Peningkatan kadar PSA dapat disebabkan oleh kanker prostat atau pembesaran prostat jinak (Benign Prostatic Hyperplasia, BPH). PSA dalam darah ditemukan dalam keadaan bebas (free PSA) dan sebagian besar diikat oleh protein (complexed-PSA, c-PSA). Pengukuran kadar PSA yang terdapat dalam darah dapat dilakukan dengan beberapa metode diantaranya dengan metode immunoradiometricassay (IRMA) ataupun metode ELISA. Metode IRMA merupakan salah satu teknik immunoassay yang menggunakan radionuklida ${ }^{125} \mathrm{I}$ sebagai perunut, sehingga cuplikan dalam jumlah kecil dapat dideteksi. Tujuan penelitian ini adalah untuk mendapatkan pereaksi kit PSA yang meliputi perunut PSA bertanda $\mathrm{I}^{125}$, coated tube PSA dan standar PSA yang memenuhi persyaratan kit sehingga selanjutnya dapat dilakukan optimasi design assay, yang pada akhirnya pereaksi kit PSA dapat digunakan untuk deteksi dini kanker prostat. Telah dilakukan penandaan MAb PSA menggunakan ${ }^{125}$ I dengan waktu reaksi selama 90 detik, jumlah MAb PSA yang digunakan adalah 75
\end{abstract}

$\mu$ gram dan aktivitas $\mathrm{Na}^{-}{ }^{125} \mathrm{I}$ sebesar $1000 \mu \mathrm{Ci}$, penyiapan coated Tube PSA dengan larutan dapar $\mathrm{Na}_{2} \mathrm{CO}_{3}$ 0,05M, pH:9,6 dengan volume $250 \mu \mathrm{L}$, standar PSA dengan dapar fosfat $0,025 \mathrm{M} \mathrm{pH} 7,4$ mengandung BSA 5\% dan 0,1 $\% \mathrm{NaN}_{3}$, dan menghasilkan NSB dan $\mathrm{B} / \mathrm{T}$ masing-masing sebesar $1,25 \%$ dan $14,12 \%$ yang memenuhi persyaratan kit.

Kata kunci : Kanker prostat, PSA, IRMA, NSB, Ikatan maksimum

\section{ABSTRACT}

Prostate Specific Antigen (PSA) is a glycoprotein with a molecular weight of approximately 34,000 daltons serine protease secreted exclusively by prostatic epithelial cells that lining acini and prostate gland. Increased of PSA levels can be caused by prostate cancer or benign prostate enlargement (benign prostatic hyperplasia, $B P H)$. PSA in the blood was found in the free condition (free PSA) and most of the bound protein (complexed-PSA, c-PSA). Measuring levels of PSA was found in the blood can be done by several methods such as by immunoradiometricassay (IRMA) methods or ELISA methods. IRMA method is one of immunoassay techniques using radionuclides of ${ }^{125} I$ as a tracer, so the sample in small 
quantity can be detected. The purpose of this study was obtained PSA reagent kit that includes ${ }^{125}$ I labeled PSA as a tracer, PSA coated tube and PSA standard that requirements of the kit, then it can be optimized assay design, that eventually PSA reagent kit can be used for early detection of prostate cancer. It has been done labeling of Mab PSA using ${ }^{125}$ I with reaction time was 90 seconds, amount of PSA MAb was 75 gram and the activity of $\mathrm{Na}^{125} \mathrm{I}$ was $1000 \mu \mathrm{Ci}$. Preaparation of PSA coated tube using $0.05 \mathrm{M}$ $\mathrm{Na}_{2} \mathrm{CO}_{3}$ solution, at $\mathrm{pH}$ : 9.6 with volume was $250 \mathrm{~mL}$, standard PSA with $0.025 \mathrm{M}$ phosphate buffer at pH 7.4 containing 5\% BSA and $0.1 \%$ $\mathrm{NaN}_{3}$, and resulting at $1,25 \%$ and $14,12 \%$ respectively of NSB and $B / T$ that requirement of the kit.

Keywords : Prostate cancer, PSA, IRMA,NSB, Maximum Binding

\section{PENDAHULUAN}

Kanker prostat merupakan kejadian kanker yang terjadi pada pria dan penyebab kematian kedua di Amerika Serikat dan ketiga di dunia. Kanker prostat adalah suatu tumor yang terdiri dari sel-sel kelenjar prostat ${ }^{(1)}$. Tumor biasanya tumbuh perlahan dan tetap terbatas pada kelenjar selama bertahun-tahun, pada tahap ini keberadaan tumor hanya sedikit menimbulkan gejala atau bahkan tidak ada gejala-gejala atau kelainan pada pemeriksaan fisik. Ketika tumor berlanjut dapat menyebar keluar dari prostat ke dalam jaringan-jaringan sekelilingnya (penyebaran lokal). Lebih dari itu, kanker dapat menyebar (bermetastasis) ke seluruh bagian tubuh, seperti tulang, paru-paru, dan hati ${ }^{(2)}$. Pada tahap awal kanker prostat tidak memiliki tanda dan gejala. Pada tahap lanjut tanda dan gejala kanker prostat antara lain : bermasalah ketika buang air kecil, berkurangnya kuantitas urin, urin yang mengandung darah, darah pada air mani, bengkak pada kaki, ketidaknyamanan pada area pinggul dan nyeri tulang ${ }^{(2)}$. Pencegahan kanker prostat dapat dilakukan dengan deteksi dini agar penyakit yang lebih parah dapat dihindari. Prostate Specific Antigen (PSA) dapat dipengaruhi oleh perubahan kelenjar prostat, misalnya Digital Rectal Examination (DRE). Setiap pria berusia di atas 50 tahun dianjurkan melakukan pemeriksaan PSA total dan DRE setiap setahun sekali, tetapi apabila ada keluarga yang menderita kanker prostat, skrining dianjurkan sejak usia 40 tahun ${ }^{(3)}$.

Prostate Specific Antigen adalah glikoprotein dengan berat molekul \pm 34.000 dalton yang diproduksi terutama oleh sel-sel epitel yang melapisi asinus dan saluran kelenjar prostat. Pada keadaan normal, hanya sedikit PSA yang masuk ke dalam aliran darah tetapi bila terjadi peradangan atau kerusakan jaringan prostat maka kadar PSA dalam darah meningkat ${ }^{(4)}$. Peningkatan kadar PSA dapat disebabkan oleh kanker prostat atau pembesaran prostat jinak (Benign Prostatic Hyperplasia, BPH). PSA dalam darah ditemukan pada keadaan bebas (free PSA) dan sebagian besar diikat oleh protein (complexedPSA, c-PSA). Pada kanker prostat peningkatan c-PSA lebih dominan dibanding konsentrasi 
free PSA, sedangkan pada BPH yang lebih dominan free PSA. Pada pria berusia lanjut $>$ 60 tahun hasil pengukuran PSA rancu apakah disebabkan oleh BPH atau kanker prostat oleh karena itu dianjurkan pemeriksaan rasio freePSA/PSA-total atau rasio c-PSA/PSA total terutama bagi mereka yang kadar PSA totalnya antara 2,6-10 $\mathrm{ng} / \mathrm{mL}$. Interpretasi pemeriksaan rasio free-PSA/PSA-total adalah $<10 \%$ diduga kanker prostat, $10 \%-25 \%$ diduga $\mathrm{BPH}$ atau kanker prostat, $>25 \%$ diduga BPH. Manfaat pemeriksaan PSA adalah untuk skrining (PSA total), untuk diagnosis (PSA total dan rasio free-PSA/PSA-total atau rasio c-PSA/PSAtotal), untuk pemantauan penyakit dan pemantauan pengobatan serta pemantauan setelah pengangkatan prostat ${ }^{(2,3,6,7)}$.

Pengukuran kadar PSA dalam darah dapat dilakukan dengan beberapa metode diantaranya metode immunoradiometricassay (IRMA) ataupun metode ELISA. Metode IRMA merupakan salah satu teknik immunoassay yang menggunakan radionuklida ${ }^{125}$ I sebagai perunut sehingga cuplikan dalam jumlah kecil dapat dideteksi. Teknik ini sangat cocok digunakan untuk penentuan tumor marker dalam serum yang mempunyai matriks yang komplek dan kadarnya yang sangat bervariasi. Teknik assay ini didasarkan pada reaksi antara antigen $(\mathrm{Ag})$ yang terdapat pada cuplikan atau standar (tumor marker) dengan antibodi yang bertanda radioaktif $\left(\mathrm{Ab}^{*}\right)$ dalam jumlah berlebih membentuk kompleks antigen- antibodi $\left(\mathrm{Ag}-\mathrm{Ab}^{*}\right)$. Dengan demikian semakin tinggi kadar tumor marker (Ag), maka kompleks antigen-antibodi yang terbentuk juga semakin tinggi sehingga akan memberikan cacahan radioaktivitas yang semakin tinggi ${ }^{(5)}$.

Kanker prostat paling banyak diderita oleh penduduk Amerika Serikat, sedangkan di Eropa lebih sedikit dari Amerika Serikat, tetapi lebih banyak di Asia Selatan dan Timur. Kanker prostat paling sering berkembang pada pria yang berumur lebih dari 50 tahun. Untuk angka kejadian di Indonesia sering pada pria berusia diatas 40 tahun dan kejadiannya terus meningkat hingga mencapai puncaknya pada usia 80 tahun ${ }^{(9)}$.

Penyebab spesifik dari kanker prostat belum pasti diketahui. Seorang pria yang beresiko terkena kanker prostat berhubungan dengan usia, genetik, ras, pola makan, gaya hidup, paparan logam Cadmium ${ }^{(2)}$ dan obatobatan serta tingkat stres yang tinggi. Faktor risiko utama adalah usia. Kanker prostat sedikit terjadi pada pria berumur kurang dari 45 tahun, tetapi bisa bertambah kemungkinannya dengan penambahan umur, umur rata-rata didiagnosis adalah 70 tahun ${ }^{(2)}$. Pria yang didiagnosa kanker prostat lebih dari $65 \%$ berusia 65 tahun ke atas dan $90 \%$ kematian yang diakibatkan oleh kanker prostat berusia diatas 65 tahun $^{(9)}$.

Pengaruh genetik terhadap perkembangan kanker prostat dapat dilihat dari adanya peningkatan kejadian kanker prostat pada ras tertentu, pria kembar identik dan pria dengan 
gen tertentu. Penelitian di Amerika menunjukkan bahwa kanker prostat lebih sering menyerang pria kulit hitam daripada kulit putih atau pria Spanyol dan lebih mematikan jika menyerang pria kulit hitam. Pria yang mempunyai kakak atau ayah dengan kanker prostat mempunyai kemungkinan dua kali lipat menderita kanker prostat. Penelitian di Skandinavia pada pria kembar menyatakan bahwa $40 \%$ risiko kanker prostat dapat dijelaskan dengan faktor bawaan. Namun, bukan hanya gen tunggal yang menyebabkan kanker prostat, banyak gen-gen berbeda yang berpengaruh. Dua gen (BRCA1 dan BRCA2) yang merupakan faktor risiko penting untuk kanker ovarium dan kanker payudara pada wanita juga berperan untuk kanker prostat ${ }^{(10)}$.

Tujuan penelitian ini adalah untuk mendapatkan pereaksi kit PSA yang meliputi perunut PSA bertanda ${ }^{125} \mathrm{I}$, coated tube PSA dan standar PSA yang memenuhi persyaratan kit, dapat dilakukan optimasi design assay dan pada akhirnya pereaksi kit PSA dapat digunakan untuk deteksi dini kanker prostat melalui penentuan kadar PSA dalam darah.

\section{BAHAN DAN METODA}

\section{Bahan}

Untuk pembuatan perunut bahan yang digunakan adalah monoklonal antibodi PSA jenis M86806M dan untuk pembuatan coated tube (CT) PSA digunakan monoklonal anti
PSA jenis M66280M, sedangkan untuk pembuatan standar PSA digunakan calibrator grade jenis $\mathrm{A} 01238 \mathrm{H}, \mathrm{Na}^{125} \mathrm{I}$, chloramine- $\mathrm{T}$, dapar Tris $0,05 \mathrm{M}$ pH 7,8; dapar $\mathrm{Na}_{2} \mathrm{CO}_{3}$ 0,05M pH 9,6; dapar $\mathrm{NaHCO}_{3}$ 0,05M pH 8,0; dapar fosfat $0,1 \mathrm{M}$ pH 7,4 dan dapar karbonat bikarbonat 0,05M pH 9,6; Bovine Serum Albumine (BSA) dan bahan kimia lainnya.

\section{Peralatan}

Peralatan yang digunakan dalam penelitian ini meliputi pencacah gamma (Gamma Management System, GMS), Gamma Mini Assay, mikro pipet ,alat pengaduk (multimix dan vortek) dan alat elektroforesa serta alat shaker.

\section{Metoda}

\section{Optimasi pembuatan perunut PSA}

Penandaan PSA dengan menggunakan MAb jenis M86806M dilakukan dengan memvariasikan waktu reaksi, jumlah MAb dan jumlah $\mathrm{Na}^{125} \mathrm{I}$ yang digunakan. Sejumlah $25 \mu \mathrm{g} / 8,5 \mu \mathrm{L}$ larutan MAb PSA didalam tabung iodinasi ditambahkan $5 \mu \mathrm{L}$ dapar fosfat 0,25 $\mathrm{M}$ pH 7,4 dan $2 \mu \mathrm{L} \quad \mathrm{Na}^{125} \mathrm{I}$ (aktivitas \pm 250 $\mu \mathrm{Ci})$, kemudian ditambahkan $5 \mu \mathrm{L}$ Chloramine- $T(0,5 \mathrm{mg}$ dalam $1 \mathrm{~mL}$ dapar fosfat $0,25 \mathrm{M} \mathrm{pH} 7,4)$. Selanjutnya campuran diaduk selama satu menit dengan menggunakan alat vortex. Kemudian ditambahkan $10 \mu \mathrm{L}$ larutan $\mathrm{Na}_{2} \mathrm{~S}_{2} \mathrm{O}_{5}(0,5 \mathrm{mg}$ $\mathrm{Na}_{2} \mathrm{~S}_{2} \mathrm{O}_{5}$ dalam $1 \mathrm{~mL}$ dapar fosfat $0,25 \mathrm{M} \mathrm{pH}$ 7,4) dan $100 \mu \mathrm{L}$ campuran KI dalam BSA $(10$ 
mg KI dan 3 mg BSA yang dilarutkan dalam dapar fosfat $0,25 \mathrm{M} \mathrm{pH}$ 7,4). Selanjutnya campuran diaduk menggunakan alat vortex selama satu menit. Hasil penandaan dimurnikan dengan menggunakan kolom sephadex G-25 superfine yang telah dikondisikan dengan dapar fosfat $0,05 \mathrm{M} \mathrm{pH}$ 7,4 dan dijenuhkan dengan $1 \mathrm{~mL}$ larutan BSA $5 \%$. Produk monoklonal anti PSA bertanda ${ }^{125} \mathrm{I}$ (selanjutnya disebut perunut ) dielusi dari kolom sephadex G-25 superfine dengan larutan dapar fosfat $0,05 \mathrm{M} \mathrm{pH} \mathrm{7,4} \mathrm{dan} \mathrm{fraksi} \mathrm{eluat}$ ditampung per fraksi dalam tabung reaksi masing-masing sebanyak $500 \mu \mathrm{L}$ eluat per fraksi sehingga diperoleh 25 fraksi. Tiap fraksi eluat diukur aktivitasnya dengan alat pencacah Gamma Mini Assay. Fraksi dengan aktivitas terbesar diuji kemurnian radiokimianya menggunakan fasa diam kertas Whatman 1 dan fasa gerak dapar barbital 0,05 M PH 8,6 dengan sistem elektroforesa selama 1 jam , 300 volt, $500 \mathrm{~mA}$. Untuk menghitung rendemen penandaan menggunakan persamaan 1, sedangkan untuk menghitung kemurnian radiokimia menggunakan persamaan 2 .

$$
\text { Rendemen Pemurnian }=\frac{\text { A }}{------X 100}
$$

Keterangan:

A :Radioaktivitas ${ }^{125}$ I dalam fraksi antibodi

B: Radioaktif awal yang digunakan

$$
\text { Kemurnian Radiokimia = ---.---- X 100\% }
$$

Keterangan:

C: Radioaktivitas bercak ${ }^{125}$ I pada KLT

D: Radioaktivitas dalam bercak produk pada KLT

\section{Optimasi pembuatan tabung bersalut} (coated tube) monoklonal antibodi PSA

Pembuatan coated tube dilakukan dengan memvariasikan larutan coatingyang digunakan (dapar Tris 0,05M pH 7,8, dapar $\mathrm{Na}_{2} \mathrm{CO}_{3}$ $0,05 \mathrm{M} \mathrm{pH} 9,6$, dapar $\mathrm{N}_{\mathrm{a}} \mathrm{HCO}_{3}$ 0,05M pH 8,0, dapar Karbonat bikarbonat $0,05 \mathrm{M}$ pH 7,4 dan dapar fosfat $0,1 \mathrm{M} \mathrm{pH} \mathrm{7,4)} \mathrm{dan} \mathrm{volume}$ coating $(100,150,200,250$ dan $500 \mu \mathrm{L})$. MAb PSA jenis M66280M. Sebanyak $250 \mu \mathrm{L}$ larutan coating dimasukkan ke dalam tabung dan diinkubasikan satu malam pada temperatur kamar $\left(25^{\circ} \mathrm{C}\right)$. Pada tahap pencucian dilakukan dengan dapar masing-masing yang mengandung Tween 20 0,05\% sebanyak 500 $\mu \mathrm{L}$. Tabung hasil pencucian di blocking dengan 
dapar masing-masing yang mengandung BSA $8 \%$ dan $0.05 \% \mathrm{NaN}_{3}$ sebanyak $500 \mu \mathrm{L}$ lalu diinkubasikan satu malam pada temperatur kamar $\left(25^{\circ} \mathrm{C}\right)$. Kemudian tabung dicuci dengan masing-masing dapar yang mengandung Tween $200,05 \%$ sebanyak $500 \mu \mathrm{L}$ satu kali, selanjutnya dikeringkan selama 8 jam.

\section{Pembuatan larutan standar PSA}

Konsentrasi larutan standar PSA yang disiapkan adalah $0,8,16,40,80$ dan 100 ng/mL. Pembuatan larutan standar PSA menggunakan Human PSA calibrator grade (Biodesign, USA) sebanyak $18 \mu \mathrm{L}$ yang dilarutkan dengan $20000 \mu \mathrm{L}$ dapar fosfat 0,025 $\mathrm{M} \mathrm{pH} \mathrm{7,4} \mathrm{dan} \mathrm{mengandung} \mathrm{BSA} \mathrm{5 \%} \mathrm{dan} 0,1 \%$ $\mathrm{NaN}_{3}$ sebagai larutan induk dengan perbandingan volume seperti pada Tabel 1.

\section{Pengujian Penentuan PSA I- ${ }^{125}$}

Dua belas tabung reaksi polistiren bersalut antibodi PSA (coted tube, CT ) diberi nomor urut (1,2 3, dan seterusnya). Sebanyak $50 \mu \mathrm{L}$ larutan standar PSA 0, 8, 16, 40, 80 dan 100 $\mathrm{ng} / \mathrm{mL}$ ditambahkan ke masing-masing tabung CT secara berurutan selanjutnya ditambahkan $100 \mu \mathrm{L}$ larutan perunut $\mathrm{PSA}^{-125} \mathrm{I}$ dengan aktivitas $\approx 100.000 \mathrm{cpm}$, kemudian dihomogenkan dengan alat vortex lalu diinkubasi selama 18 jam pada suhu ruangan. Cairan dibuang dan tabung CT dicuci dengan $500 \mu \mathrm{L}$ dapar pencuci sebanyak satu kali, kemudian didekantasi dan dikeringkan. Radioaktivitas yang tertinggal di dalam tabung diukur dengan alat pencacah Gamma Management System (GMS) selama satu menit.

Tabel 1. Perbandingan volume pada pembuatan larutan standar PSA.

\begin{tabular}{|c|c|c|c|}
\hline No. & $\begin{array}{c}\text { Konsentrasi larutan } \\
\text { standar PSA } \\
\text { (ng/mL) }\end{array}$ & $\begin{array}{c}\text { Volume larutan } \\
\text { induk Human PSA } \\
(\mu \mathrm{L})\end{array}$ & $\begin{array}{c}\text { Volume larutan dapar fosfat } 0,025 \\
\text { M pH 7,4 yang mengandung BSA } \\
5 \% \text { dan } \mathrm{NaN}_{3} 0,1 \%(\mu \mathrm{L})\end{array}$ \\
\hline 1 & 0 & 10000 & 0 \\
\hline 2 & 8 & 80 & 9920 \\
\hline 3 & 16 & 160 & 9840 \\
\hline 4 & 40 & 400 & 9600 \\
\hline 5 & 80 & 800 & 9200 \\
\hline 6 & 100 & 1000 & 10000 \\
\hline
\end{tabular}

(\%NSB) digunakan persamaan 3 sedangkan ditentukan dengan rumus 4., sebagai berikut:

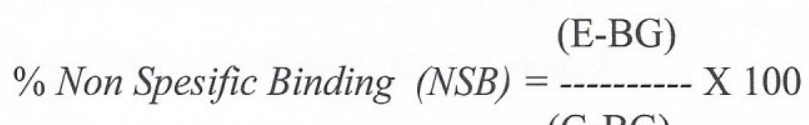

Keterangan:

(G-BG)

E: Cacahan NSB

G: Cacahan Total

BG: Background 


$$
\text { \% Maximum Binding (B/T) = - }
$$

Keterangan:

$\mathrm{H}$ : Cacahan fasa terikat

I: Cacahan total

\section{HASIL DAN PEMBAHASAN}

\section{Optimasi pembuatan perunut $\mathrm{PSA}^{-125}$ I}

Optimasi pembuatan perunut PSA- ${ }^{125} \mathrm{I}$ dilakukan dengan memvariasikan lama waktu reaksi, jumlah MAb PSA dan aktivitas $\mathrm{Na}^{125} \mathrm{I}$ yang digunakan. Dengan variasi waktu antara 30 sampai 120 detik pada reaksi MAb PSA dengan $\mathrm{Na}^{125} \mathrm{I}$ diperoleh waktu reaksi optimum pada 90 detik yang memberikan rendemen pemurnian tertinggi sebesar 82,95\% (Gambar 1) dan kemurnian radiokimia perunut PSA tertinggi sebesar $\quad 86,90 \%$ (Gambar 2) dibandingkan dengan waktu reaksi 30, 60 dan 120 detik. Dengan waktu reaksi selama 30 detik diperoleh rendemen pemurnian sebesar $74,58 \%$ dan kemurnian radiokimia sebesar $68,17 \%$ selanjutnya untuk lama waktu reaksi 60 detik diperoleh rendemen pemurnian sebesar $73,22 \%$ dan kemurnian radiokimia sebesar $86,87 \%$ serta untuk lama waktu reaksi 120 detik diperoleh rendemen pemurnian sebesar $83,15 \%$ dan kemurnian radiokimia sebesar $82,40 \%$ seperti pada Gambar 3 .

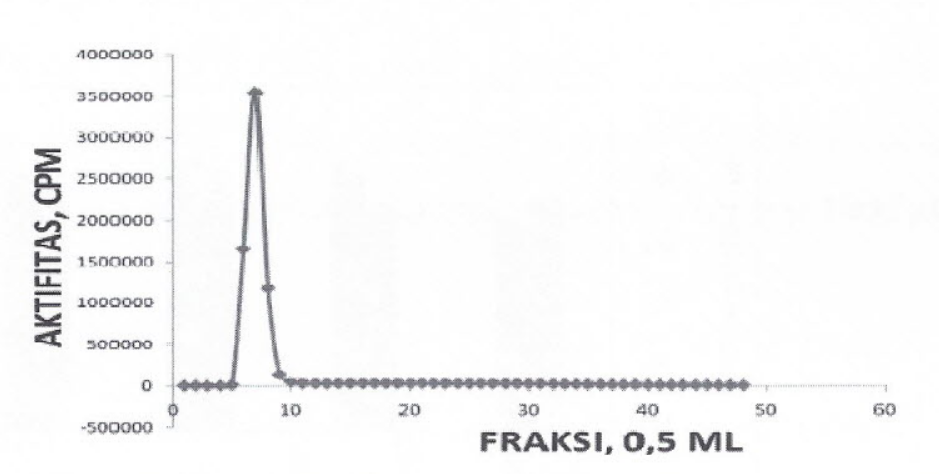

Gambar 1. Radiokromatogram hasil penandaan MAb PSA M86806M dengan $\mathrm{Na}^{125}$ I menggunakan kolom sephadex G-50 superfine dengan pengelusi dapar fosfat $0,05 \mathrm{M} \mathrm{pH} 7,4$ yang memberikan rendemen pemurnian sebesar $82,95 \%$. 


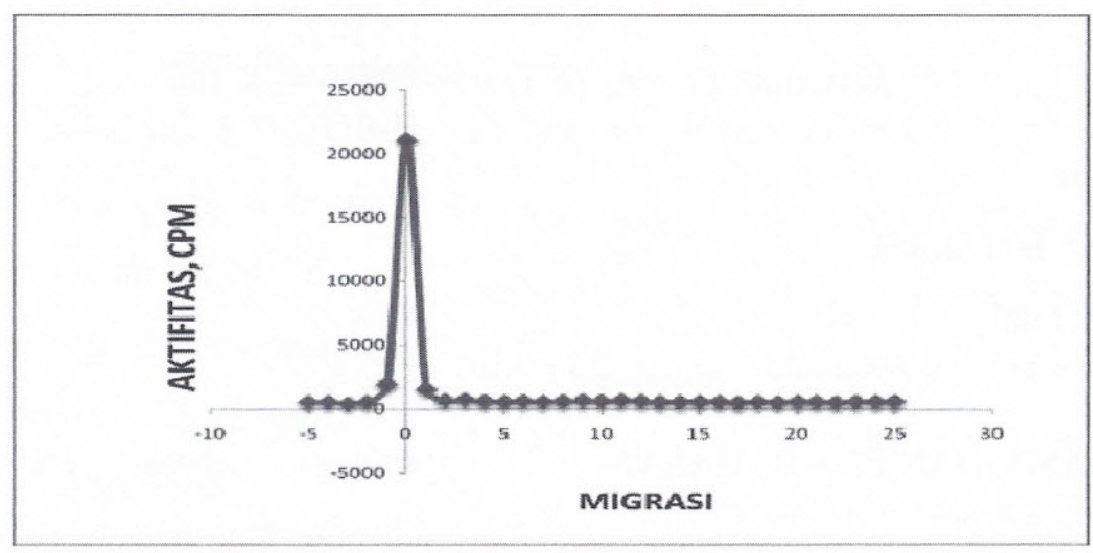

Gambar 2. Radiokromatogram PSA- ${ }^{125}$ I dengan menggunakan fasa diam kertas whatman 1 dan fasa gerak dapar barbital $0,05 \mathrm{M} \mathrm{pH} 8,6$ dengan sistem elektroforesa selama 1 jam, 300 volt, kemurnian $86,90 \%$

Pada Gambar 3 menunjukkan bahwa Hal ini disebabkan ikatan MAb PSA dengan dengan lama waktu reaksi antara MAb PSA

${ }^{125}$ I yang terbentuk sudah optimum sehingga dengan $\mathrm{Na}^{125} \mathrm{I} 30$ dan 60 detik memberikan dengan penambahan waktu reaksi yang hasil rendemen pemurnian yang tidak berbeda dilakukan tidak mempengaruhi rendemen tetapi hasil kemurnian radiokimia terlihat pemurnian yang diperoleh. Oleh karena itu adanya perbedaan yang nyata sedangkan selanjutnya dalam pembuatan perunut PSA ini dengan lama waktu reaksi 90 detik diperoleh digunakan waktu reaksi selama 90 detik. rendemen dan kemurnian radiokimia tertinggi.

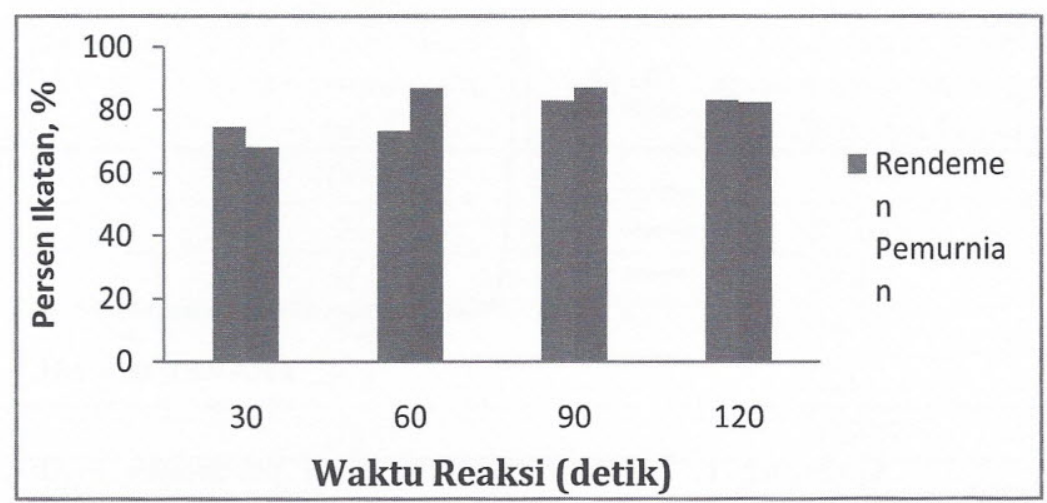

Gambar 3. Pengaruh lama waktu reaksi antara MAb PSA dengan $\mathrm{Na}^{25}$ I terhadap rendemen pemurnian dan kemurnian radiokimia perunut PSA

Pada variasi jumlah MAb PSA yang kemurnian radiokimia perunut PSA yang digunakan antara $12,5,25,50,75$ dan 100 dihasilkan sebesar 89,57\%, sedangkan pada $\mu$ gram diperoleh jumlah MAb PSA yang penggunaan MAb PSA 12,5, 25, 50 dan 100 optimum terjadi pada $75 \mu$ gram dengan $\mu$ gram berturut-turut memberikan rendemen rendemen pemurnian sebesar $85,6 \%$ dan pemurnian $75,19 \%, 76,25 \%, 82,69 \%$ dan 
$82,20 \%$ serta kemurnian radiokimia sebesar pembuatan perunut PSA akan digunakan $64,04 \%, 72,01 \%, 71,85 \%$ dan 79,45\% (Gambar jumlah MAb PSA sebanyak $75 \mu$ gram.

4), sehingga untuk selanjutnya dalam

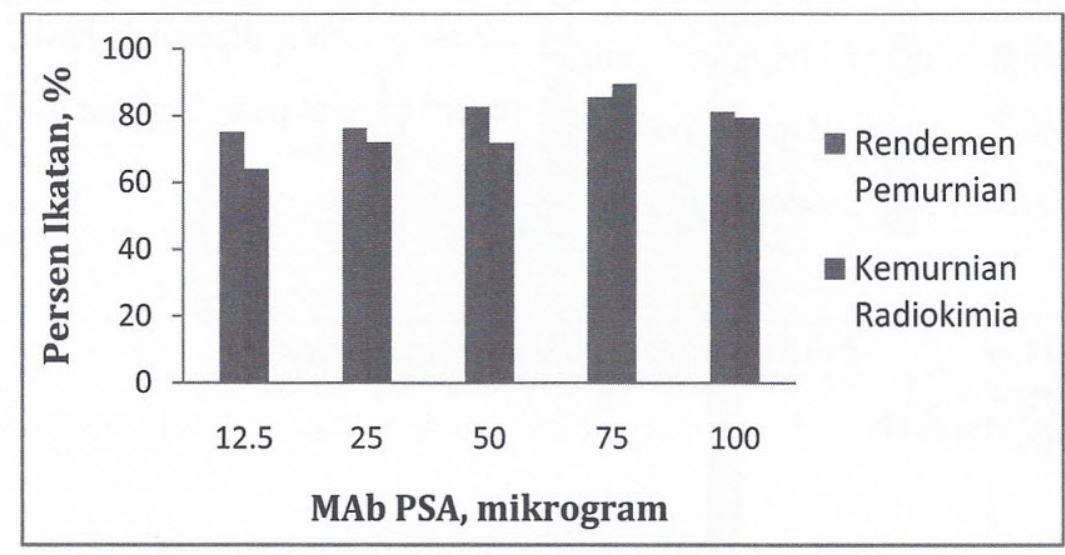

Gambar 4. Pengaruh MAb PSA yang digunakan terhadap rendemen pemurnian dan kemurnian radiokimia perunut PSA yang dihasilkan.

Pada variasi aktivitas $\mathrm{Na}^{125} \mathrm{I}$ yang aktivitas $\mathrm{Na}^{125} \mathrm{I} 250,500,750$ dan $1000 \mu \mathrm{Ci}$ digunakan yaitu antara 250,500,750,1000 dan berturut-turut memberikan rendemen $1250 \mu \mathrm{Ci}$ diperoleh aktivitas $\mathrm{Na}^{125} \mathrm{I}$ yang pemurnian sebesar 83,31\%, 70,13\%, 82,94\% optimum adalah pada $1000 \mu \mathrm{Ci}$. Pada aktivitas dan $81,38 \%$ serta kemurnian radiokimia sebesar sebesar $1000 \mu \mathrm{Ci}$ tersebut dapat memberikan 77,70\%, 85,79\%, 93,69\% dan 93,49\% seperti rendemen pemurnian sebesar $83,26 \%$ dan pada Gambar 5. Dengan demikian untuk kemurnian radiokimia perunut PSA yang selanjutnya dalam pembuatan perunut PSA ini dihasilkan sebesar $98 \%$ sedangkan penggunaan digunakan aktivitas sebesar $1000 \mu \mathrm{Ci}$.

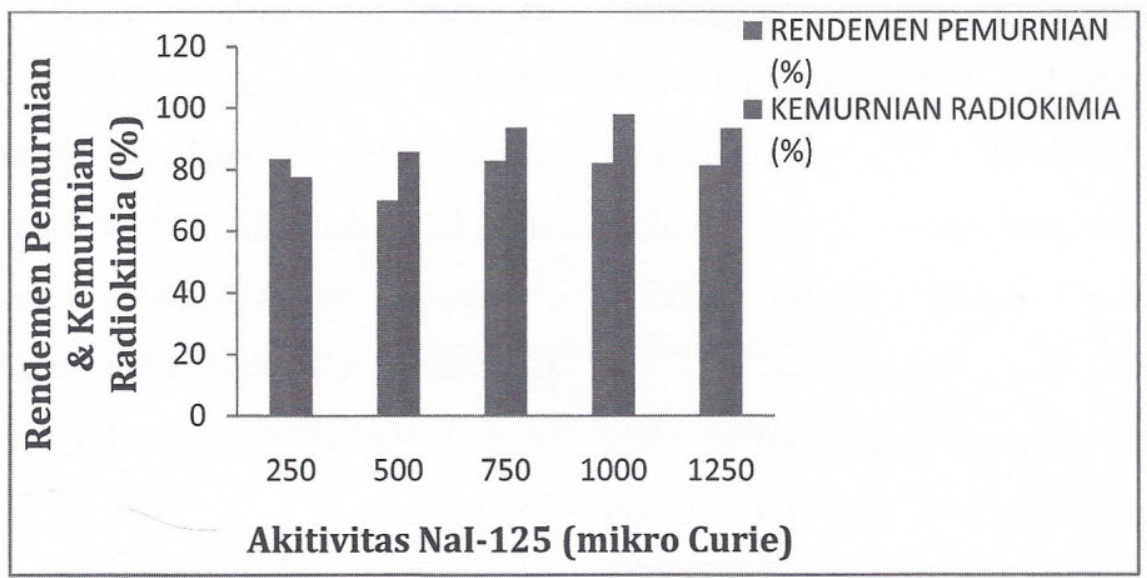

Gambar 5. Pengaruh Aktivitas $\mathrm{Na}^{125} \mathrm{I}$ yang digunakan terhadap rendemen pemurnian dan kemurnian radiokimia perunut PSA yang dihasilkan. 
Optimasi pembuatan coated tube (CT) PSA

Optimasi pembuatan coated tube (CT) PSA dilakukan dengan memvariasikan dapar coating dan volume dapar coating yang digunakan. Untuk variasi dapar coating digunakan lima macam dapar coating yaitu Tris
0,05M, pH:7,8, $\mathrm{Na}_{2} \mathrm{CO}_{3} \quad 0,05 \mathrm{M}, \quad \mathrm{pH}: 9,6$, $\mathrm{NaHCO}_{3}$ 0,05M, pH:8,0, Fosfat 0,1M, pH:7,4 dan karbonat bikarbonat 0,05M, pH:9,6. Dengan variasi tersebut diperoleh hasil uji immunologi seperti terlihat pada Gambar 6.

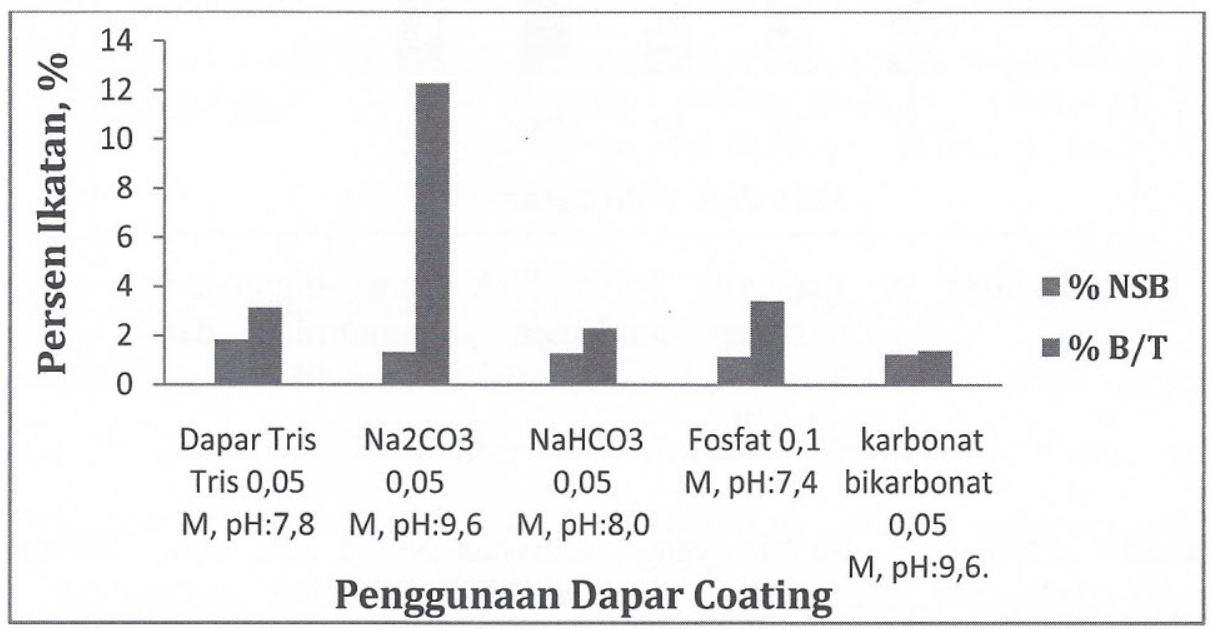

Gambar 6. Pengaruh penggunaan dapar coating terhadap $\%$ NSB dan $\% \mathrm{~B} / \mathrm{T}$

Pada Gambar 6 dapat dilihat bahwa penggunaan dapar $\mathrm{Na}_{2} \mathrm{CO}_{3}$ 0,05M dengan $\mathrm{pH}$ : 9,6 untuk coating memberikan hasil ikatan antigen antibodi yang maksimum $(\% \mathrm{~B} / \mathrm{T})$ yaitu $12,27 \%$ dibandingkan dengan penggunaan dapar coating yang lain. Sedangkan ikatan tidak spesifik (\%NSB) sebesar 1,33\% sehingga untuk selanjutnya dalam pembuatan CT PSA ini akan digunakan dapar coating $\mathrm{Na}_{2} \mathrm{CO}_{3} \quad 0,05 \mathrm{M}$, dengan $\mathrm{pH}: 9,6$.

Pada variasi volume dapar coating yang digunakan yaitu antara 100, 150, 200, 250 dan $500 \mu \mathrm{L}$, memberikan hasil \%NSB yang tidak

begitu berbeda tetapi hasil $\% \mathrm{~B} / \mathrm{T}$ terlihat nyata perbedaanya, tetapi semakin besar peggunaan volume coating \% B/T yang diperoleh semakin besar dan diperoleh kondisi optimum pada 250 $\mu \mathrm{L}$ yang memberikan $\% \mathrm{~B} / \mathrm{T}$ sebesar 14,12 , sehingga dengan penambahan volume coating menjadi $500 \mu \mathrm{L}$ tidak menambah $\% \mathrm{~B} / \mathrm{T}$ nya yaitu 12,27 dapat dilihat pada Gambar 7.

Dengan demikian untuk selanjutnya dalam pembuatan CT PSA akan digunakan dapar coating $\mathrm{Na}_{2} \mathrm{CO}_{3}$ 0,05M, pH:9,6 dengan volume $250 \mu \mathrm{L}$. 


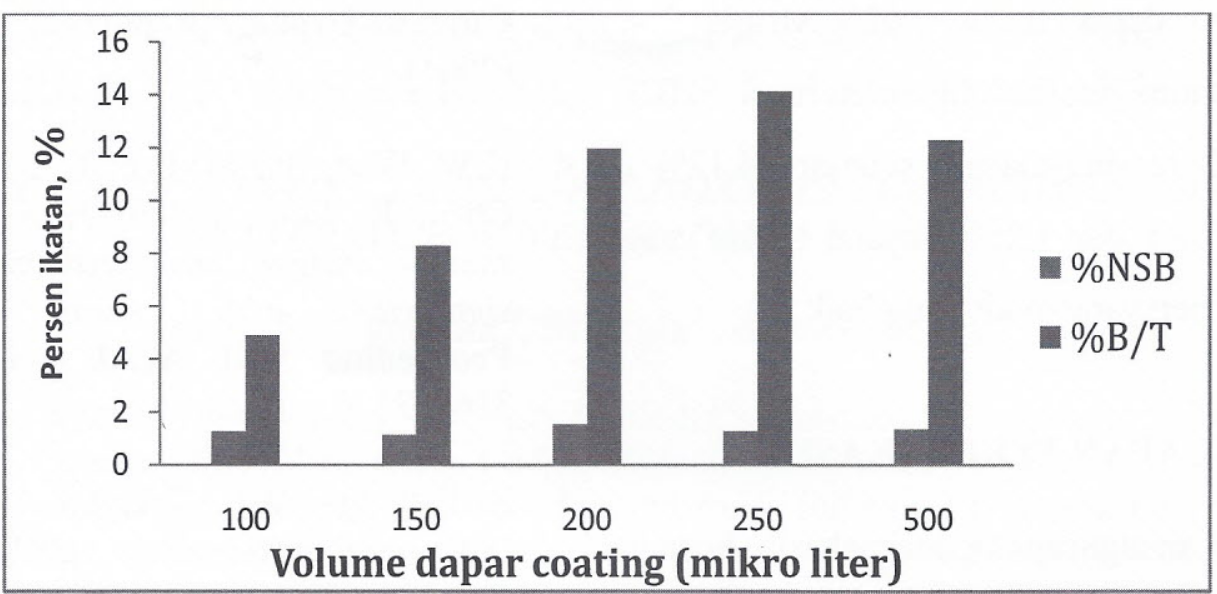

Gambar 7. Pengaruh volume coating terhadap \% NSB dan \%B/T

\section{Pembuatan larutan standar PSA}

Dalam pembuatan larutan standar PSA ini dilakukan dengan cara mengencerkan baku PSA (A0128H) dengan menggunakan dapar fosfat $0,025 \mathrm{M} \mathrm{pH}$ 7,4 yang mengandung Bovine Serum Albumine (BSA) sebesar 5\% dengan konsentrasi $0,8,16,40,60$ dan $100 \mathrm{ng} / \mathrm{mL}$. Dengan kondisi PSA sebagai standar diperoleh kurva kalibrasi standar yang ditunjukkan pada
Gambar 7.

Pada Gambar 7 dapat dilihat hubungan konsentrasi standar PSA $(\mathrm{ng} / \mathrm{mL})$ dengan ikatan maksimum $(\% \mathrm{~B} / \mathrm{T})$ dengan tingkat kepercayaan tinggi yang ditunjukkan oleh nilai $\mathrm{R}^{2} 0,9938$ dengan persamaan garis regresi $\mathrm{Y}=0,1247 \mathrm{X}+$ 1,7099. Dengan demikian standar PSA yang dibuat dapat digunakan untuk penentuan kadar PSA.

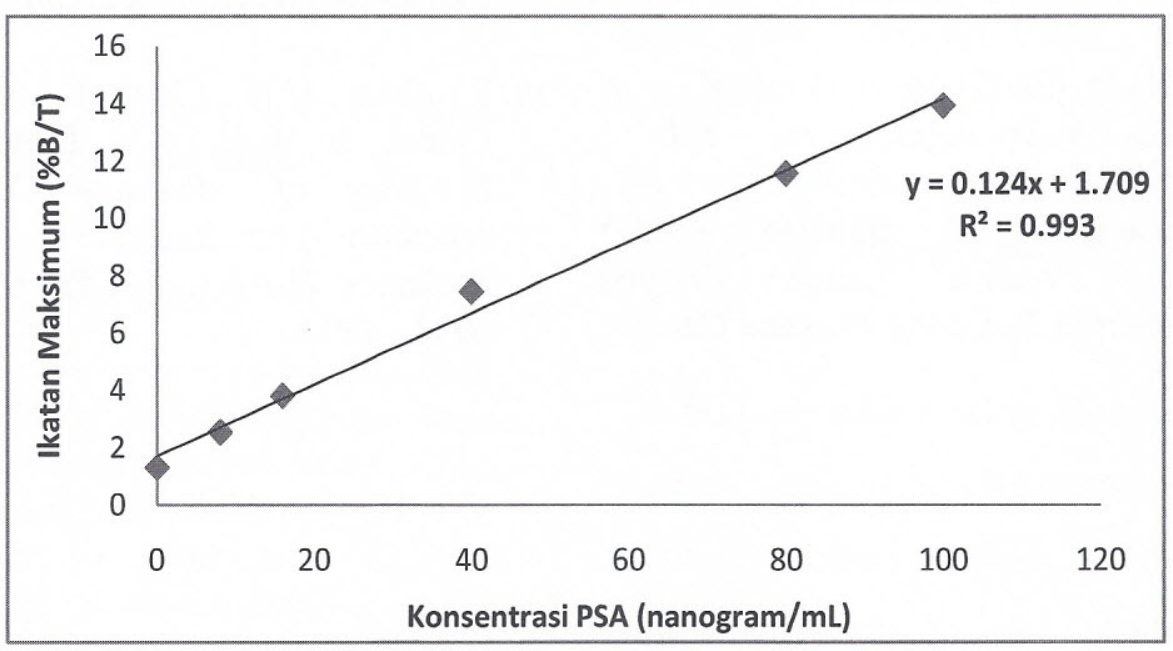

Gambar 7. Kurva kalibrasi standar PSA

\section{KESIMPULAN}

Telah dibuat pereaksi kit IRMA PSA perunut PSA dengan kondisi optimum pembuatan pada : lama waktu reaksi 90 detik, menggunakan MAb PSA sebanyak $75 \mu$ gram dan aktivitas $\mathrm{Na}^{125} \mathrm{I}$ sebesar $1000 \mu \mathrm{Ci}$; CT PSA dengan dapar coating $\mathrm{Na}_{2} \mathrm{CO}_{3} 0,05 \mathrm{M}$ pH 9,6 dengan volume $250 \mu \mathrm{L}$ dan larutan standar 
PSA dalam dapar fosfat $0,025 \mathrm{M} \mathrm{pH} \mathrm{7,4.}$ Dengan kondisi tersebut diperoleh hasil \%B/T dan $\%$ NSB masing-masing sebesar 14,12\% syarat $>10 \%$ ) dan $1,25 \%$. 9syarat $<2 \%$ ) yang memenuhi persyaratan kit yang baik.

\section{UCAPAN TERIMAKASIH}

Penulis mengucapkan terimakasih kepada staf bidang Radioisotop dalam penyediaan Radioisotop $\mathrm{Na}^{125} \mathrm{I}$, staf bidang Radiofarmaka dan tim Komisi Pembina Tenaga Peneliti (KPTP) di instansi PRR yang memberi masukan sehingga penelitian berjalan sesuai yang direncanakan.

\section{DAFTAR PUSTAKA}

1. C. Pfister, J.P. Basuyau. (2005) Current usefulness of free/total PSA ratio in the diagnosis of prostate cancer at an early stage. World J Urol. 23: 236-242. DOI 10.1007/s00345-005-0506-4

2. W. A. Schulz, (2005) Molecular Biology of Human Cancer, Springer, pp 383-386

3. K. Okihara, R. J. Babaian. (2001) Complexed Prostate Spesific Antigen Improvement in Detecting Prostate Cancer.
Current Urology Reports. 2 : $253-258$ (2001)

4. K.W. Watt, P.J.M. Lee, T. Timkulu, W.P. Chan, R. Loor, (1986) Human prostatespecific antigen: structural and functional similarity with serine proteases, Proceeding Natl. Acad. Sci. USA, pp. 3166-3170.

5. Rediatning W, Sukiyati Dj, (2000) Immunoraiometricassay (IRMA) Dalam Deteksi dan pemantauan Kanker, $J$. Radioisotop dan Radiofarmaka. 3. 55 - 70

6. Development of kit for radioimmunometric assays for tumor markers Final report of a coordinated research project, 1997-2001, IAEA-TECDOC-1307, August, 2002

7. A.F. Moghadam, P. Stieber. (1991) Sensible use of tumour markers, Edition Roche, Basel, Switzerland, pp 44-45

8. N. Schmeller, (2005) Clinical value of PSA, 1st edition, Bremen: UNI-MED, pp 14-22

9. K.O.H. William, M. Hurwitz, A. V D'Amico, J. P. Richie, P. W. Kantoff, Neoplasms of the Prostate, Holland-Frei Cancer Medicine. 5th edition

10. P. Zhou, M.H. Chen, D. McLeod, P.R. Carrol, J. Moul, A.V. D'Amico, (2005) Predictor of Prostate Cancer-Spesific Mortality after Radical Prostatectomy of Radiation Therapy, J. Clin. Oncol, 23 (28) $6992-6998$ 